\title{
Deposit Money Banks' Credit and Agricultural Sector Performance in Nigeria
}

\section{EKINE Data I. and ONUKWURU Fyneface Manunyewho}

\author{
Department of Agricultural and Applied Economics and Extension, Faculty of Agriculture, Rivers
} State University, Nkpolu- Oroworukwo, Port Harcourt.

\section{ARTICLE INFO}

\section{ABSTRACT}

Article No.: 031218042

Type: Research

DOI: 10.15580/GJAS.2018.3.031218042

Submitted: 11/03/2018

Accepted: 15/03/2018

Published: 31/03/2018

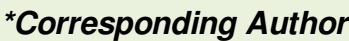

Fyneface M. $O$.

E-mail: fynefacem@yahoo.com

Keywords: Deposit Money Banks Interest Rate, Banks Credit, Government Agricultural Sector.
The study empirically examines the effect of deposit money banks credit on agricultural sector performance in Nigeria from 1986 to 2016. The data for the empirical analysis was sourced from secondary data sources various issues of the CBN statistical bulletin. The study used agricultural sector output (ASP) to proxy agricultural sector performance as the dependent variable whereas Deposit Money Banks' Credit to Agricultural Sector (BCA) was the major explanatory variable while Interest Rate (INR) and Government Expenditure on Agriculture (GEA) are the check regressors as to enhance the explanatory power of the model. The study employed descriptive statistic, Ordinary Least Squares (OLS), unit root test, co-integration and ECM methods of analysis as the analytical tools. The results revealed that there is no co-integrating (or long run) relationship between deposit money banks' credit to agricultural sector and the performance of agricultural sector in Nigeria during the period of study; Deposit money banks' credit to agricultural sector (BCA) had a positive and a significant impact on Agricultural Sector performance (ASP); Interest Rate (INR) had a negative insignificant relationship with Agricultural Sector performance (ASP). Also, the study revealed that government expenditure on agricultural sector (GEA) had a positive insignificant relationship on Agricultural Sector performance (ASP). Consequent upon the above, it is recommended that efforts should be made by the government and private individuals to encourage or increase investment in the agricultural sector. The lending rate on loans to the Expenditure, agricultural sector should be reviewed and fixed at a rate that would encourage farmers to acquire loans from deposit money banks. 


\section{INTRODUCTION}

Nigeria, like most other countries in the continent of African, is not only endowed with vast agricultural farmland, but also a conducive geographical condition that favours agricultural production throughout the year. Despite this great potential, there is not much to show for it (Agunuwa et al., 2015 and Salami and Arawomo, 2013).

Several studies in this area including Enyim, Ewno and Okoro (2013), have identified poor credit supply as one of the factors accounting for the poor performance of the agricultural sector in Nigeria. According to Obilor (2013), banks, precisely the deposit money banks, obviously have no kin interest in financing agriculture. In order to encourage the banks, the government established the Agricultural Credit Guarantee Scheme (ACGS) to provide guarantees against inherent risk in agricultural lending. This measure could not achieve the intended objectives because agricultural, being both a labour and capital intensive venture, requires huge capital outlay (Nwankwo, 2013). Consequently, the country with it highly diversified agro-econological condition is relying on massive importation of basic food items and raw materials for industrial inputs (Agunuwa et al 2015). The resultant effect of the high cost of living coupled with high level of unemployment on the common man is beyond reasonable imagination. Obviously, the government's effort to fortify the Nigeria agricultural sector has not yielded the desired result (Udensi, Orebiyi, Ohajianya and Eze, 2012). Thus, the persistence of these problems in spite of various policy measures adopted by various governments to strengthen the agricultural sector makes it imperative to investigate empirically the effect of deposit money banks' credit on agricultural sector performance in Nigeria.

\section{LITERATURE REVIEW}

\subsection{Theoretical Framework}

\section{Commercial Loan Theory of Liquidity}

Commercial loan theory of liquidity also known as the real bills doctrine was developed by Adam Smith in 1776. Adam Smith use this theory to explain the bank liquidity that short-term loans advanced to finance salable goods on the way from producer to consumer are the most liquid loans the bank can make. These are self-liquidating loans because the goods being financed will soon be sold. The loan finances a transaction and the transaction itself provides the borrower with the funds to repay the bank. According to Adam Smith these loans are liquid because their purpose and their collateral were liquid. The goods move quickly from the producers through the distributors to the retail outlet and then are purchased by the ultimate cash-paying consumer.

\section{Multiple Lending Theory}

This theory reveals that banks should be less inclined to share lending (loans syndication) in the presence of welldeveloped equity markets and after a precise consolidation. Both outside equity, mergers and acquisitions increase banks' lending capacities, thus reducing their need for greater diversification and monitoring through share lending (Ewert, Szczesmy and Schenk, 2000; Ongene and Smith 2000; and Ajie, Ezi, Akekere and Ewubare, 2006). This theory has a greater implication for banks in Nigeria in the light of the recent 2005 consolidation exercise in the industry. In this line of argument, the classical system views the interest rate, exchange rate, deposit rate, and financial ratio of banks as strong and uncompromising factors that determines granting of loans and advances to private individuals and corporate organisations. This is called the real theory of interest rate. This is because these factors do not in any way depend on monetary conditions. Meanwhile, in the classical system, the supply of capital is the same as saving.

\subsection{Empirical Literature}

Many studies have examined the effect of deposit money banks' credit on agricultural sector performance of countries. For instance, Egbetunde (2012) examines the relationship between commercial bank credits indicators and rural economic growth in Nigeria. The study used Ordinary Least Square (OLS) and cointegration test for the analysis. The study found that a positive relationship between rural economic growth and commercial bank rural loans as well as commercial bank loans to agriculture and rural economic growth exist, while deposits of rural dwellers were negatively impacted on rural economic growth. Based on these results, the study recommends that commercial bank credits in the development of economic activities in rural areas should be properly managed in order to improve the well-being of the rural dwellers which in turn improve economic growth in Nigeria.

Ogege and Shiro (2013) examine the role of banks deposit money in the growth of Nigerian economy from 1974 to 2010. The study used unit root test, cointegration and error correction modeling technique for the analysis. At the end of our analysis, we discovered that there exist a long-run relationship between the dependent and the explanatory variables. The results conform to the economic a priori expectation. Thus, policies that tend to increase the gross domestic product through the financial sector such as increase in banks deposit liability, low interest rate, high liquidity ratio were recommended for better economy.

Uzomba, Chukwu, Jumbo and Nwankwo (2014) investigated the impact and the determinants of Deposit 
Money Banks' loans and advances granted to agricultural sector in Nigerian sector from 1980 to 2011. The study employed rigorous econometric methods such as the multiple OLS regression, Philips Perron, Unit Root Stationarity Test, Johnansen Co-integration, Parsimonious Error Correction Mechanism and Granger Causality Test to analyze the data. The results of the study revealed that the overall model is statistically significant. Based on this, the study concluded that deposit money banks' loans and advances did make positive impact on the agricultural sector of Nigerian within the period of review. The study therefore recommended that the Federal Government and Monetary Authorities should respectively use expansionary fiscal and monetary policies to expand the volume of loans and advances that are given to agricultural sector of Nigeria.

Uzonwanne (2015) examined deposit money banks' credit and financing medium and small scale enterprises in Nigeria from 1995 to 2012. The study employed the descriptive method. Findings from the estimation shows that deposit money banks in Nigeria have been lacking in this aspect. As a result, recommendations were made for its stability and sustainability such that the monetary authority should initiate policies that would redirect the channel of deposit money banks' credits so as to meet the borrowing needs of at least $65 \%$ of the medium and small scale enterprises in the economy. This will help to boost economic activities within the country because lack of capital retards investment.

Anthony, Gabriel, and Arikpo (2015) investigate the effect of deposit money banks credit on the growth of the agricultural sector in Nigeria between the periods 1988 to 2011. They used the ordinary least squares method of multiple regression to analyze the data. Result from the analysis revealed that both deposit money banks loans and the agricultural credit guarantee scheme fund had a positive relationship with the output of the agricultural sector. It was however discovered that agricultural credit guarantee scheme fund's relationship was insignificant. The study also revealed that deposit money bank lending rate had a negative and insignificant relationship with the output of the agricultural sector in Nigeria. Based on these findings, it recommended that the loans and finances to the agricultural sector should be increased while the lending rate should be reduced.

Iwedi, Igbanibo, and Onuegbu (2015) examined the impact of bank domestic credits on the economic growth of Nigeria using time series data for the period of thirty three (33) years spanning from 1980 to 2013. The study employed the augmented Dickey-Fuller unit root test and OLS to analyze the data. The study shows that credit to the private sector (CPS) and Credit to the government sector (CGS) positively and significantly correlate with GDP in the short run. The analysis revealed the existence of poor long run relationship between bank domestic credit indicators and gross domestic product in Nigeria. This study recommends that the managers of the Nigerian economy should fashion out appropriate policies that will enhance the bidirectional flow of influence between the banking sector where investable funds are sourced and the real sector of the economy where goods and services are produced.

Ajudua, Ojima and Okonkwo (2015) examines the impact of monetary policy variables on the agricultural sector in Nigeria from 1986 - 2013. The study employed the unit root test, Johansen cointegration and ordinary least square (OLS) regression methods for the analysis. The study revealed that there exist a relationship between monetary policy and agricultural sector performance in Nigeria with an increase in the budgetary allocation to agricultural sector, and the effective utilization of these allocated funds, an effective and prudent management of monetary policies with concessionary low interest rate to encourage investment in the sector all proffered as recommendations to improve the agricultural sector.

Nnamocha and Eke (2015) investigated the effect of Bank Credit on Agricultural Output in Nigeria using the Error Correction Mode (ECM) from 1970 to 2013. ) The analysis showed that all the variables were integrated of order one I (1) and long-run relationship existed among them. However, following the empirical findings in this study, it showed that, in the long-run bank credit and industrial output contributed a lot to agricultural output in Nigeria, while; only industrial output influenced agricultural output in the short-run.

Agunuwa, Inaya and Proso (2015) examine the impact of commercial banks' credits on agricultural productivity in Nigeria. The statistical tools employed were unit root test and the Ordinary Least Squares (OLS) techniques. The study revealed that commercial banks credit has a positive significant relationship with agricultural productivity; interest rate has a negative relationship with agricultural productivity; government spending has a positive significant with agricultural productivity in Nigeria. Based on the findings, they recommended that the Agricultural Credit, Guarantee Scheme should improve on their conditions for credit guarantee in order to make agricultural financing attractive to commercial banks.

Ali, Jatau and Ekpe (2016) examined the impact of deposit money banks' credit on agricultural output in Nigeria from 1981 to 2014. The study used the ordinary least squares method, unit root test, Variance Inflation Factor (VIF) and Heterosckedasticity white Test were used for the analysis of the data. Findings of the regression analysis revealed that deposit money banks' credit significantly and positively affected agricultural output while the result for Deposit Money Banks' lending rate (DMBLR) shows that DMBLR has an inverse and insignificant impact on Agricultural output (AQ). Also the trend in the deposit money banks' credit to the agricultural sector contained in the CBN bulletin increased considerably within the period under study. There was, however, a sharp decline in loan stock in 2007. Thus, the study concludes that Deposit Money banks' credit is a viable source of finance for sustainable 
growth in the agricultural sector. The study therefore recommends that Deposit Money banks' should increase the volume of credit facilities to the agricultural sector to sustain food production for the teeming population of Nigeria.

Maxwell and Egbeonu (2016) empirically examined sectoral loans demand and performances of deposit money banks using unit root test, Johannsen cointegration, multiple OLS regression analysis, granger causality test, impulse response analysis and variance decomposition test. The result revealed that loans and advances to agriculture, mining and quarrying sectors have negatively contributed to the performances of banks while manufacturing and real estate construction sectors contributed positively to the performances of deposit money banks. It is therefore recommended that banks should increase their loans to the less preferred sectors (agriculture, mining and quarrying sectors) on the ground that government will fully guarantee such loans as these sectors will have improved performances consequently leading to increase performances of deposit money banks in the future and the overall growth of the economy.

Udoka, Mbat, and Duke (2016) examined the effect of commercial banks' credit on agricultural output in Nigeria. The study used the ordinary least squares method of regression technique to analyze the data. The study showed that there was a positive and significant relationship between agricultural credit guarantee scheme fund and agricultural production in Nigeria; there was a positive and significant relationship between commercial banks credit to the agricultural sector and agricultural production in Nigeria; there was a positive and significant relationship between government expenditure on agriculture and agricultural production in Nigeria and a negative relationship between interest rate and agricultural output also confirmed theoretical postulations. The study recommended that there was the need for the government to continue to guarantee loans lent to farmers as this would encourage the banks to lend more to farmers.

\subsection{Summary of literature reviewed and research gap}

From the literature reviewed, it was observed that many studies have been done on the effect of deposit money banks' credit on agricultural sector performance of countries. This study differs in some way from existing ones. One, this study focuses specifically on the period, 1986-2016. Theoretically, this study adopts the Commercial loan theory of liquidity for the model. This is so because the theory identifies the fact that the economic growth of nation depends on the agricultural sector performance. This is achieved through deposit money banks' financing the agricultural sector. Finally, the study employed ECM modeling technique for the analysis. To the best of our knowledge, none of the studies reviewed have fill this gap in literature, hence, form the basis for this study.

\section{METHODOLOGY}

\subsection{Data Sets}

The data for this study are annual time series collected from secondary sources covering a period of thirty one years, from 1986 to 2016. Some of these sources include publications of the Central Bank of Nigeria (CBN) statistical bulletin.

Data were collected on the following variables- Output of Agricultural Sector (ASP), Deposit Money Banks' Credit to Agriculture (BCA), Interest Rate (INR) and Government Expenditure on Agriculture (GEA) from 1986 to 2016.

\subsection{Analytical Framework}

This study employed the Commercial loan theory of liquidity to model the relationship between deposit money banks' credit on agricultural sector performance in Nigeria. The theory states that a commercial bank should forward only short-term self-liquidating productive loans to business organizations. Loans meant to finance the production, and evolution of goods through the successive phases of production, storage, transportation, and distribution are considered as selfliquidating loans. Thus, the model is specified as:

$A S P=f(B C A)$

Equation (3.1) is modified to include interest rate (INR) and government expenditure on agriculture. The inclusion of these variables is justified because deposit money banks charge interest (INR) for parting with liquidity and Udoka et al. (2016) asserted that the sole provider of capital resources and financial incentives for the agricultural sector over the years has been the government. Thus the functional form of the model is specified as:

$A S P=f(B C A, I N R, G E A)$

Where;

ASP $=$ Agricultural Sector Performance

$\mathrm{BCA}=$ Deposit Money Banks' Credit to Agricultural Sector

INR = Interest Rate

GEA $=$ Government Expenditure on Agricultural Sector

Accordingly, the econometric form of the model is:

$A S P_{t}=\beta_{0}+\beta_{1} B C A_{t}+\beta_{2} I N R_{t}+\beta_{3} G E A_{t}+\mu_{t}$

Where:

$A S P_{t}=$ Output of Agricultural Sector at time ' $t$ '

$\mathrm{CBL}_{t}=$ Deposit Money Banks' Credit to Agricultural Sector at time ' $\mathrm{t}$ ' 
$I N R_{t}=$ Interest rate at time ' $\mathrm{t}$ '

$G E A_{t}=$ Government Expenditure on Agricultural Sector at time ' $\mathrm{t}$ '

$\beta_{i}=$ Parameter estimates

$\mu_{\mathrm{t}}=$ Error term.

The a priori expectations are stated as:

$\beta_{1}$ and $\beta_{3}>0$ while $\beta_{2}<0$

We also tried the log-linear specification on the relationship in equations (3.2). That is, non-linear form of the relationship. So, the Cobb-Douglas (i.e. aggregate production function) variety was specified, estimated and compared with the linear version.

The log-linear specification was adopted to place all the variables in the models on the same scale or level and to minimize the problem of multicolinearity.

Hence, the Cobb-Douglas (aggregate production function) variety for the model is specified as follows:

$A S P_{t}=\beta_{0}\left(B C A_{t}\right)^{\beta 1}\left(I N R_{t}\right)^{\beta 2}\left(G E A_{t}\right)^{\beta 3} \mu_{t}$

Equation (3.3) was transformed into log to enable the model amenable to OLS as follows:

$$
\operatorname{LOG}\left(A_{S P}\right)=\operatorname{LOG}\left(\beta_{0}\right)+\beta_{1} L O G\left(B C A_{t}\right)+\beta_{2} L O G\left(I N R_{t}\right)+\beta_{3} L O G\left(G E A_{t}\right)+\mu_{t}
$$

\subsection{Estimation Techniques}

This study adopted descriptive statistics as well as Ordinary Least Squares (OLS) of multiple regression analysis for this study. In order to achieve this, the unit root model test, co-integration as well as Error Correction Mechanism (ECM) approach were also used to model the relationship between deposit money banks' credit on agricultural sector performance in Nigeria.

\section{DISCUSSION OF RESULTS}

The empirical analysis of data in this paper was conducted in five phases. It begins with the descriptive statistics analysis of the data and thereafter conducted the unit test. Furthermore, long run estimation analysis, co-integration, and the granger causality tests were conducted.

\subsection{Descriptive Statistics}

Table 1 below presents the result of the descriptive statistics of the variables employed in the estimations in this study. It shows that output of agricultural sector (ASP) averaged about 7867489.0 and varied from 2891672.0 to 15952220 with a standard deviation of 4599329.0 within the period under review.

Table 1: Descriptive Statistics Results

\begin{tabular}{lcccc}
\hline & ASP & BCA & INR & GEA \\
\hline Mean & 7867489. & 108772.4 & 18.82365 & 17294.41 \\
Median & 5024542. & 48561.50 & 17.98000 & 7537.355 \\
Maximum & 15952220 & 482390.2 & 29.80000 & 65399.01 \\
Minimum & 2891672. & 1830.300 & 10.50000 & 20.68884 \\
Std. Dev. & 4599329. & 144272.9 & 3.835670 & 19617.96 \\
Skewness & 0.467647 & 1.525251 & 0.908123 & 0.928641 \\
Kurtosis & 1.633774 & 3.982721 & 4.443897 & 2.670180 \\
Jarque-Bera & 3.540907 & 13.26709 & 6.953798 & 4.596109 \\
Probability & 0.170256 & 0.001315 & 0.030903 & 0.100454 \\
Sum & $2.44 \mathrm{E}+08$ & 3371944. & 583.5332 & 536126.6 \\
Sum Sq. Dev. & $6.35 \mathrm{E}+14$ & $6.24 \mathrm{E}+11$ & 441.3710 & $1.15 \mathrm{E}+10$ \\
Observations & 31 & 31 & 31 & 31 \\
\hline \multicolumn{5}{c}{ Source: Author's Computation (2018) }
\end{tabular}

Source: Author's Computation (2018)

The result also shows that deposit money banks' credit to agricultural sector (BCA) averaged 108772.4 and varied from 1830.30 to 482390.2 ; interest rate (INR) averaged 18.82 and varied from 10.50 to 29.80; while government expenditure to agricultural sector (GEA) averaged $17294.41 \mathrm{a}$ and ranged from 20.68884 to 65399.01 with a standard deviation of 19617.96 within the period of study.

Furthermore, one important observation about Table 1 is the values of Skewness and Kurtosis. All the skewness values are positive, meaning that the distribution has a long right tail and the kurtosis values of ASP and GEA were platykurtic, suggesting that their distribution were flat relative to normal, INR and BCA were leptokurtic, suggesting that their distribution were peaked relative to normal.

From the result of the summary statistics we observe that the mean for the variables exhibit significant variation in terms of magnitude, suggesting estimation in levels may introduce some bias in the 
results. Based on these observations, it indicates that the series are non-stationary. However, this indication is not surprising since it involves time series data. Time series data are subject to fluctuations caused by many different events which may be positive or negative. Thus, the series may be positive at one point and negative in another. In sum, there is unit root (non-stationarity) in the series. In such a case, the presence of unit root in the model is further supported by the values of the JarqueBera statistic for BCA and INR variables which are above 5.99 depicting the presence of unit root.

Based on the above observations it is therefore necessary to test for unit root. We also tested for co- integration among the variables and conducted the ECM. As hitherto discussed in chapter three, the study proceed by conducting the unit root test to make the variables stationary using the Dickey and Fuller (1979) method called Augmented Dickey Fuller (ADF) tests.

\subsection{Unit Root Test}

Tables 2 present the results of the stationarity test for each of the variables used in this study. The Augmented Dickey Fuller (ADF) test was tested with intercept but no trend.

Table 2: ADF Unit Root Test Results at Level

\begin{tabular}{|c|c|c|c|c|c|}
\hline \multicolumn{7}{|c|}{ Augmented Dickey Fuller (ADF) Test } \\
\hline Variables & Level & $\begin{array}{c}5 \% \text { Critical } \\
\text { Values }\end{array}$ & $1^{\text {st }}$ Diff. & $\begin{array}{c}5 \% \text { Critical } \\
\text { Values }\end{array}$ & Status \\
\hline LOG(ASP) & -0.244355 & -2.963972 & -5.058079 & -2.967767 & $\mathrm{I}(1)$ \\
\hline LOG(BCA) & -1.135198 & -2.963972 & -6.166588 & -2.967767 & $\mathrm{I}(1)$ \\
\hline LOG(INR) & -4.920932 & -2.963972 & - & - & $\mathrm{I}(0)$ \\
\hline LOG(GEA) & -2.287506 & -2.967767 & -7.609798 & -2.967767 & $\mathrm{I}(1)$ \\
\hline
\end{tabular}

Source: Author's Computation (2018)

The results of the unit root test in table 2 reveals that INR variable was stationary at level while ASP, BCA, and GEA variables were stationary in their first differences. We then concluded that the variables of the model are integrated of order one. Having stabilized and stationarized the data, we now conduct the long run regression and co-integration tests.

\subsection{Long Run Regression Results}

The long run regression results for ASP model is presented in Tables 3 below. The result shows that the calculated $R^{2}$ is 0.871905 , meaning that about 87 percent of the total variations in ASP are caused by the regressors BCA, INR and GEA. Thus, the remaining 13 percent of variations are caused by exogenous factors to the model but covered by the error term. Also, the Fstatistic calculated of 61.26029 is greater than the table value of 2.95. This means that the overall model is significant at 5 percent level. The value of the D.W. of 0.363 is far from 2. This indicates that there is presence of serial autocorrelation. This no withstanding, since the f-statistic is highly significant the result can be used for policy formulations.

Table 3: Long Run Regression Results

\begin{tabular}{|c|c|c|c|c|}
\hline $\begin{array}{l}\text { Dependent Variable: } \\
\text { Method: Least Squar } \\
\text { Sample: } 19862016 \\
\text { Included observation }\end{array}$ & & & & \\
\hline Variable & Coefficient & Std. Error & t-Statistic & Prob. \\
\hline $\mathrm{C}$ & 12.72148 & 0.874592 & 14.54563 & 0.0000 \\
\hline LOG(BCA) & 0.318525 & 0.073517 & 4.332662 & 0.0002 \\
\hline LOG(INR) & -0.175076 & 0.222618 & -0.786441 & 0.4385 \\
\hline LOG(GEA) & 0.014806 & 0.051011 & 0.290255 & 0.7738 \\
\hline R-squared & 0.871905 & Mean depeı & ht var & 15.70390 \\
\hline Adjusted R-squared & 0.857672 & S.D. depen & var & 0.606038 \\
\hline S.E. of regression & 0.228636 & Akaike info & erion & 0.006545 \\
\hline Sum squared resid & 1.411412 & Schwarz cri & & 0.191576 \\
\hline Log likelihood & 3.898548 & Hannan-Qui & riter. & 0.066861 \\
\hline F-statistic & 61.26029 & Durbin-Wat & stat & 0.363075 \\
\hline Prob(F-sta & 0.000000 & & & \\
\hline
\end{tabular}

Source: Author's Computation (2018)

\subsection{Cointegration Results}

The Engle and Granger two step procedure argues that although the individual series may not be integrated of 
the same order but a linear combination of the series will produce a co integrated series. Hence we proceed to estimate the number of the co-integrated equations using Johanson and Juselius (1990) procedure. This provides evidence for the long run stability of the system and further validates its efficiency for prediction, forecast and policy recommendations. The result of the cointegration test is presented in the table below.

Table 4: Cointegration Test Results

\begin{tabular}{|c|c|c|c|c|}
\hline \multicolumn{5}{|c|}{ Unrestricted Cointegration Rank Test (Trace) } \\
\hline \multirow{2}{*}{$\begin{array}{c}\text { Hypothesized } \\
\text { No. of CE(s) }\end{array}$} & & Trace & 0.05 & \multirow{2}{*}{ Prob.** } \\
\hline & Eigenvalue & Statistic & $\begin{array}{l}\text { Critical } \\
\text { Value }\end{array}$ & \\
\hline None & 0.500014 & 31.77005 & 47.85613 & 0.6248 \\
\hline At most 1 & 0.184420 & 11.66795 & 29.79707 & 0.9427 \\
\hline At most 2 & 0.145058 & 5.756128 & 15.49471 & 0.7241 \\
\hline At most 3 & 0.040906 & 1.211211 & 3.841466 & 0.2711 \\
\hline \multicolumn{5}{|c|}{$\begin{array}{l}\text { Trace test indicates no cointegration at the } 0.05 \text { level } \\
{ }^{*} \text { denotes rejection of the hypothesis at the } 0.05 \text { level } \\
\qquad{ }^{* *} \text { MacKinnon-Haug-Michelis (1999) p-values }\end{array}$} \\
\hline \multicolumn{5}{|c|}{ Unrestricted Cointegration Rank Test (Maximum Eigenvalue) } \\
\hline Hypothesized & & Max-Eigen & 0.05 & Prob. ${ }^{\star *}$ \\
\hline No. of CE(s) & Eigenvalue & Statistic & $\begin{array}{l}\text { Critical } \\
\text { Value }\end{array}$ & \\
\hline None & 0.500014 & 20.10211 & 27.58434 & 0.3341 \\
\hline At most 1 & 0.184420 & 5.911818 & 21.13162 & 0.9846 \\
\hline At most 2 & 0.145058 & 4.544917 & 14.26460 & 0.7978 \\
\hline At most 3 & 0.040906 & 1.211211 & 3.841466 & 0.2711 \\
\hline \multicolumn{5}{|c|}{$\begin{array}{l}\text { Max-eigenvalue test indicates no cointegration at the } 0.05 \text { level } \\
{ }^{*} \text { denotes rejection of the hypothesis at the } 0.05 \text { level } \\
{ }^{* *} \text { MacKinnon-Haug-Michelis (1999) p-values }\end{array}$} \\
\hline
\end{tabular}

The co-integration results in table 4 for the model reveal that, both the trace test and the Max-eigenvalue test indicates no co-integration at the 5 percent level of significance. This suggests that there is no co-integrating (or long run) relationship between the deposit money banks' credit to agricultural sector and the performance of agricultural sector in Nigeria within the period of study. The study therefore accepts the null hypothesis of no cointegration amongst the variables.

In line with the above, Omoke (2010) have argued that when the co-integration test of any result indicates no co-integration, then there is no need to further subject the variables to error correction test rather the causality test should be done and the long run result be used to analyze the findings. Since the null hypothesis is accepted, there is no need to further subject the variables to error correction test. So, the focus should be to analyze the Ordinary Least Squares (OLS) results and the causality between the variables used in this study.

\subsection{Granger Causality Results}

Pairwise Granger Causality test between the dependent and independent variables were examined in Tables 5 . This is to determine the direction of causality amongst the economic variables used in our study. The Pairwise Granger Causality tests were conclusive at 5 percent level of significance.

Table 5: Pairwise Granger Causality Tests Results

Pairwise Granger Causality Tests

Sample: 19862016

Lags: 2 


\begin{tabular}{lccc}
\hline Null Hypothesis: & Obs & F-Statistic & Prob. \\
\hline LOG(BCA) does not Granger Cause LOG(ASP) & 29 & 0.61233 & 0.5503 \\
LOG(ASP) does not Granger Cause LOG(BCA) & & 0.86715 & 0.4329 \\
LOG(INR) does not Granger Cause LOG(ASP) & 29 & 0.39275 & 0.6795 \\
LOG(ASP) does not Granger Cause LOG(INR) & & 4.23100 & 0.0267 \\
LOG(GEA) does not Granger Cause LOG(ASP) & 29 & 0.65318 & 0.5294 \\
LOG(ASP) does not Granger Cause LOG(GEA) & & 0.62470 & 0.5439 \\
\hline
\end{tabular}

Source: Author's Computation (2018)

The result indicates a unidirectional causality running from ASP to INR while no causality runs from BCA, INR, and GEA to ASP in Nigeria within the period under review.

\subsection{Discussion of the Findings}

The study reveals that the regression coefficient of LOG(BCA) is 0.318525, indicating a positive relationship between BCA and ASP. This is in line with the a priori expectation implying that for every 10 percent increase in BCA has the effect of increasing ASP by 3.19 percent and this effect is significant at 5 percent level. This is because the t-value calculated of 4.3327 is greater than the t-table of 2.052. The implication of this is that as BCA increases ASP also increases in Nigeria within the period under review. This finding corroborates previous studies such as Ogar et al. (2015), Agunuwa et al. (2015), Nnamocha and Eke (2015) and Udoka et al. (2016).

Furthermore, the study reveals that the regression coefficient of $\mathrm{LOG}(\mathrm{INR})$ is -0.175076 , indicating a negative relationship between INR and ASP. This is in line with the a priori expectation implying that for every 10 percent increase in INR has the effect of decreasing ASP by 1.75 percent and this effect is insignificant at 5 percent level. This is because the tvalue calculated of 0.7864 is less than the t-table of 2.052. The implication of this is that as INR increases ASP decreases but the effect is insignificant in Nigeria within the period under review. This finding is in accord with previous studies such as Ogar et al. (2015), Agunuwa et al. (2015), and Udoka et al. (2016).

Also, the study reveals that the coefficient of LOG(GEA) is 0.014806, indicating a positive relationship between GEA and ASP. This is in line with the a priori expectation, implying that for every 10 percent increase in GEA has the effect of increasing ASP by 0.15 percent and this effect is not significant at 5 percent level. This is because the t-value calculated of 0.2903 is less than the t-table of 2.052. The implication of this is that as GEA increases ASP also increases in Nigeria but the effect is insignificant within the period under review. This finding supports previous studies such as Agunuwa et al. (2015), and Udoka et al. (2016).
This study examined the nexus between deposit money banks' credit to agricultural sector and the performance of agricultural sector in Nigeria from 1986 to 2016. The study adopted the descriptive statistics, the Ordinary Least Square (OLS) estimation method, unit root test, cointegration and granger causality test to analyze the data. The study found that there is no cointegrating (or long run) relationship between the deposit money banks' credit to agricultural sector and the performance of agricultural sector; Deposit money banks' credit to agricultural sector $(B C A)$ has a positive and a significant impact on Agricultural Sector performance (ASP); Interest Rate (INR) has a negative insignificant relationship with Agricultural Sector performance (ASP); Government expenditure on agricultural sector (GEA) has a positive insignificant relationship impact on Agricultural Sector performance (ASP); and no causality runs from BCA, INR, and GEA to agricultural sector performance (ASP) in Nigeria but a unidirectional causality runs from ASP to INR within the period under review.

\section{RECOMMENDATIONS}

In light of the above findings, the paper recommends as follows:

(i) Effort should be made by the government and private individuals to encourage or increase investment in the agricultural sector.

(ii) The lending rate on loans to the agricultural sector should be reviewed and fixed at a rate that would encourage farmers to acquire loans from deposit money banks.

(iii) Government should subsidized interest rate to the agricultural sector and stop fuel subsidy as this will provide more benefit to the society than the fuel subsidy. (iv) The government should formulate policies that will encourage the banks to give loans to farmers at a concessionary interest rate.

(v) Also, the government should make deliberate efforts to expand its agricultural expenditure by increasing its financial grants to agricultural firms and small scale farmers.

\section{CONCLUSION}

\section{REFERENCES}


Agunuwa, E. V., Inaya, L., \& Proso, T. (2015). Impact of commercial banks' credit on agricultural productivity in Nigeria (Time Series Analysis 1980 - 2013). International Journal of Academic Research in Business and Social Sciences, 5(11) 337-350. DOI: 10.6007/IJARBSS/v5-i11/192.

Ajie, H. A., Ezi, C. T., Akekere, J., \& Ewubare, D. B. (2006). Financial Institutions, Markets and Contemporary Issues, (2006), Pearl Publisher, Port Harcourt.

Ajudua, E. I., Ojima, D., \& Okonkwo, O. N. (2015). A review of monetary policy and the Nigerian agricultural sector performance. International Journal of Academic Research in Progressive Education and Development, 4(3), 70-86. DOI: 10.6007/IJARPED/v4-i3/178.

Ali, J. I., Jatau, S., \& Ekpe, M. J. (2016). Financial intermediation and agricultural output in Nigeria: An impact analysis of deposit money banks' credit. International Journal of Agricultural Economics, 1(1), 16-25. doi: 10.11648/j.ijae.20160101.13.

Anthony, O., Gabriel, E. E., \& Arikpo, O. F. (2015). The contribution of deposit money banks on the growth of the agricultural sector in Nigeria. Advances in Social Sciences Research Journal, 3(2), 33-42. DOI: 10.14738/assrj.32.1009.

Egbetunde, T. (2012). Bank credits and rural development in Nigeria (1982-2009). International Journal of Finance and Accounting, 1(3), 45-52. DOI: 10.5923/j.ijfa.20120103.04.

Enyim, O. B., Ewno, E. N. \& Okoro, O. T. (2013). Banking sector credit and the performance of the agricultural sector in Nigeria. European Journal of Scientific Research, 23(2), $35-55$.

Ewert, R., Szczesmy, A., \& Schenk, G. (2000). Determinants of Bank Lending Performance in Germany, (2000), Norway Publication.

Iwedi, M., Igbanibo, D. S., \& Onuegbu O. (2015). Bank domestic credits and economic growth nexus in Nigeria (1980-2013). International Journal of Finance and Accounting, 4(5), 236-244. DOI: 10.5923/j.ijfa.20150405.02.

Johansen, S., \& Juselius, K. (1990). Maximum likelihood estimation and inference on co-integration- with applications to the demand for money. Oxford Bulletin of Economics and Statistics, 52, 169-210.

Maxwell, U. \& Egbeonu, O. C. (2016). Sectoral loans demand and performances of deposit money banks in Nigeria. International Journal of Accounting Research (IJAR), 2(10), 28- .

Nnamocha, P. N., \& Eke, C. N. (2015) Bank credit and agricultural output in Nigeria (1970 - 2013): An error correction model (ECM) approach. British Journal of
Economics, Management \& Trade, 10(2), 1-12. DOI: 10.9734/BJEMT/2015/1988

Nwankwo, O. (2013). Agricultural financing in Nigeria: An empirical study of Nigerian agricultural cooperative and rural development bank (NACRDB): 1990 - 2010. Journal of Management Research, $5(2), 28-44$.

Obilor, S. I. (2013). The impact of commercial banks' credit to agriculture

on agricultural development in Nigeria: An econometric analysis. International Journal of Business Humanities and Technology, 3(1), 85 - 95.

Ogar, A., Gabriel, E. E., \& Arikpo, O. F. (2015). The contribution of deposit money banks on the growth of the agricultural sector in Nigeria. Advances in Social Sciences Research Journal, 3(2), 33-42. DOI: 10.14738/assrj.32.1009.

Ogege, S., \& Shiro, A. A. (2013). Does depositing money in bank impact economic growth? Evidence from Nigeria. African Journal of Business Management, 7(3), 196-205. DOI: 10.5897/AJBM12.932.

Omoke, P. C. (2010). Inflation and economic growth in Nigeria. International journal of Academic Research in Business and Social Sciences, 5(11), 337-350.

Ongene, S., \& Smith, D.C. (2000). What determines the number of bank relationships? Crosscountry evidence. Journal of Financial Intermediation, 9(2), 26-56.

Salami, A. \& Arawomo, D. F. (2013). Empirical analysis of agricultural credit in Africa: Any role for institutional factors? Tunis, Tunisia, Africa Development's Work Paper, Series

Udensi, A. I., Orebiyi, J. S., Ohajianya, D. O. \& Eze, C. C. (2012). Determinants of macroeconomic variables that affect agricultural production in Nigeria. International Journal of Agric and Rural Development, 15(3), 1169 - 1173.

Udoka, C. O., Mbat, D. O., \& Duke, S. B. (2016). The effect of commercial banks' credit on agricultural production in Nigeria. Journal of Finance and Accounting, 4(1), 1-10. DOI:10.12691/jfa-4-1-1

Uzomba, P. C., Chukwu, S. N., Jumbo, G. A., \& Nwankwo, N. U. (2014). An inquiring into the impact of deposit money banks' loans/advances on agricultural sector in Nigeria; 1980 - 2011. International Review of Social Sciences and Humanities, 7(2), 130-139.

Uzonwanne, M. C. (2015). Deposit money banks and financing of small and medium scale enterprises in Nigeria. Journal of Economics and Sustainable Development, 6(8), 185-195. 